\title{
KEMAMPUAN KOMUNIKASI MATEMATIS SISWA SMA MELALUI PENERAPAN METODE KOOPERATIF TIPE INVESTIGASI KELOMPOK
}

\author{
Mardiati \\ Prodi Pendidikan Matematika, STKIP Budidaya Binjai, Indonesia \\ Email : mardiati2208@gmail.com
}

\begin{abstract}
ABSTRAK
Penelitian ini bertujuan untuk mengetahui peningkatan kemampuan komunikasi matematis siswa kelas X SMA melalui penerapan metode kooperatif tipe investigasi kelompok pada pembelajaran matematika. Populasi dalam penelitian ini adalah seluruh siswa kelas X SMA Negeri 1 Selesai tahun pelajaran 2019/2020. Sampel dalam penelitian ini terdiri dari 2 kelas, yaitu kelas X-MIA1 sebagai kelas dengan menerapkan pembelajaran investigasi kelompok berjumlah 36 siswa dan kelas X-MIA2 sebagai kelas dengan menerapkan pembelajaran konvensional berjumlah 36 siswa. Jenis penelitian ini adalah penelitian eksperimen semu dengan menggunakan posttest only control group design. Data pretes dan postes yang digunakan berdistribusi normal, memiliki varians yang sama atau bersifat homogen, dan memiliki kesamaan rata-rata. Hasil penelitian ini adalah terdapat pengaruh signifikan penerapan metode kooperatif tipe investigasi kelompok terhadap kemampuan komunikasi matematis siswa SMA.
\end{abstract}

\section{Kata kunci : Investigasi Kelompok, Kemampuan Komunikasi Matematis}

\section{PENDAHULUAN}

Standar isi untuk satuan pendidikan dasar dan menengah mata pelajaran Matematika (Peraturan Mentri Pendidikan Nasional No. 22 Tahun 2006 tanggal 23 Mei 2006) disebutkan bahwa "salah satu tujuan pembelajaran matematika adalah supaya siswa memiliki kemampuan mengkomunikasikan gagasan dengan simbol, tabel, diagram, atau media lain untuk memperjelas keadaan atau masalah". Sejalan dengan salah satu tujuan pembelajaran matematika menurut NCTM adalah belajar untuk berkomunikasi (mathematical communication)". Kemampuan komunikasi matematika siswa jika telah menguasai indikator yang direkomendasikan NCTM (2000) sebagai berikut: (1)dapat menyatakan ide matematik dengan lisan, tulisan, mendemonstrasikan dan menggambarkan dalam bentuk visual, (2)dapat memahami, menginterpretasikan dan menilai ide matematik yang disajikan dalam bentuk tulisan atau visual, (3)dapat menggunakan bahasa, notasi dan struktur matematik untuk menyajikan ide, menggambarkan hubungan pembuatan model. Sumarmo (2005:20), menyatakan indikator komunikasi matematis adalah sebagai

berikut:1)Menghubungkan benda nyata, gambar, dan diagram ke dalam ide matematika; 2)Menjelaskan ide, situasi dan relasi matematik secara lisan atau tulisan dengan benda nyata, gambar, grafik dan aljabar; 3)Menyatakan peristiwa sehari-hari dalam bahasa simbol matematika; 4)Mendengarkan, berdiskusi, dan menulis tentang matematika; 5)Membaca dengan pemahaman suatu presentasi matematika tertulis; 6)Membuat konjektur, menyusun argument, merumuskan definisi dan generalisasi; 7)Menjelaskan dan membuat pertanyaan tentang matematika yang telah dipelajari.

Untuk mengetahui tingkat kemampuan komunikasi siswa SMA peneliti melakukan studi pendahuluan pada siswa di SMA Negeri 1 Selesai. Peneliti memberikan soal materi Sistem Persamaan Linier Tiga Variabel (SPLTV). Soal yang digunakan dalam studi pendahuluan ini akan mengukur kemampuan komunikasi siswa SMA pada indikator: 1)Menjelaskan ide, situasi dan relasi matematik secara lisan atau tulisan dengan benda nyata, 


\section{Jurnal Serunai Ilmu Pendidikan \\ Vol.6, No.1, Juni 2020 \\ e-ISSN $2621-2676$ \\ p-ISSN 2528 - 0775}

gambar, grafik dan aljabar; 2)Menyatakan peristiwa sehari-hari dalam bahasa simbol matematika; 3)dapat menggunakan bahasa, notasi dan struktur matematik untuk menyajikan ide, menggam-barkan hubungan pembuatan model.

Hasil studi pendahuluan diperoleh bahwa masih banyak siswa yang belum menguasai indikator dari kemampuan komunikasi matematis. Rata-rata kemampuan komunikasi matematis siswa masih rendah atau dengan kata lain masih sedikit siswa yang memiliki kemampuan menyelesaikan soal komunikasi matematis pada materi SPLTV.

Hasil wawancara dengan siswa perihal alasan kenapa mereka tidak mampu dalam menyelesaikan soal SPLTV, siswa kesulitan dalam memahami soal dan bagaimana langkahlangkah dalam penyelesaian soalnya. Siswa tidak mampu mengubah bentuk soal cerita kedalam notasi/symbol matematika. Siswa kurang memahami penjelasan dari guru karena menurut pendapat mereka soal yang dicontohkan lebih mudah penyelesaiannya dibandingkan dengan soal yang menjadi tugas mereka.

Hasil wawancara dengan guru matematikanya, mengatakan bahwa ketika diberi penjelasan materinya siswa kurang aktif dalam memperhatikan gurunya dan sangat sedikit siswa yang bertanya ketika sebenarnya mereka belum paham dengan penjelasan materimya. Artinya dalam hal ini kurangnya interaksi siswa dengan guru bahkan juga siswa dengan sesama siswa mengakibatkan proses penerimaan materi kurang optimal.

Kesimpulan dari hasil wawancara dengan beberapa orang siswa bahwa penggunaan metode pembelajaran yang tidak melibatkan siswa mengakibatkan siswa bosan,tidak peduli dan tidak berminat terhadap pembelajaran. Proses pembelajaran cenderung membosankan dapat menyebabkan siswa menjadi kurang aktif dan menciptakan suasana yang membuat siswa takut untuk belajar apalagi belajar matematika.

Melihat keadaan seperti ini perlu sebuah tindakan yang dilakukan agar penyerapan materi ajar bisa optimal. Dalam hal ini perlu adanya perubahan proses belajar dari siswa dan juga proses pengajaran dari gurunya. Siswa dituntut keaktifannya dalam belajar dan guru dituntut kreativitasnya dalam mengelola pembelajaran yang menyenangkan dan mengaktifkan siswa.

Ketika siswa ikut terlibat dalam proses pembelajarnnya dan siswa diberi tanggung jawab untuk menentukan sendiri masalah matematika yang akan mereka selesaikan kemudian merencanakan tugas dan mencari penyelesaian masalah dan selanjutnya mereka akan merangkum hasil kerja mereka. Hasil yang mereka peroleh akan dapat dipertanggunjawabkan melalui presentasi hasil kerja. Ketika proses ini diterapkan dengan bantuan guru sebagai fasilitator, siswa akan mudah dalam memahami materi.

Adapun tahapan proses pembelajaran seperti tersebut diatas terdapat pada model pembelajaran investigasi kelompok. Melalui investigasi kelompok siswa akan diajak menjadi individu yang akan selalu menerapkan model belajar aktif dapat mengomunikasikan dengan benar mengenai apa yang telah mereka pelajari.

Slavin membagi tahapan dalam pelaksanaan model pembelajaran investigasi kelompok yaitu, tahap grouping, tahap planning, tahap investigation, tahap organizing, tahap presenting, dan tahap evaluating.

Pembelajaran model investigasi kelompok dimulai dengan pembagian kelompok yang diarahkan oleh guru agar tidak terjadi kesenjangan kemampuan.(Dimyati:2009). Menurut Arensd 
(2008), model pembelajaran ini, siswa diberikan kuasa penuh untuk memilih sendiri topik dari pembelajaran sehingga tahu gambaran yang akan dipelajari dan cara menjalankan investigasinya. selanjutnya siswa berdiskusi memilih permasalahan dan topik/sub topik tertentu. siswa berdiskusi bersama temannya merencanakan penyelesaian permasalahan. Setiap kelompok berkerja berdasarkan rencana penyelidikan yang mereka rumuskan. Aktivitas tersebut merupakan kegiatan sistematik keilmuan mulai dari mengumpulkan data, analisis data, sintesis, hingga menarik kesimpulan.

Model pembelajaran investigasi kelompok merupakan model pembelajaran yang memberikan kemungkinan bagi siswa untuk mengembangkan pemahaman melalui berbagai kegiatan yang biasanya dimulai dengan soal-soal atau masalah-masalah (Al. Krismanto, dan Widyaiswara. 2003).

Tabel 1. Tahapan Pembelajaran Investigasi Kelompok

Tahap 1 Grouping: guru mengatur siswa dalam kelompok dan meminta perwakilan kelompok untuk mengambil amplop sub topik yang berisi permasalahan tentang:

(1) Metode Eliminasi

(2) Metode Substitudi

(3) Metode Campuran (Eliminasi dan Substitusi)

Tahap 2 Planning: siswa merencanakan penyelesaian permaslahan yang menjadi tugas kelompok

Tahap 3 Investigation: siswa melaksanakan investigasi yang telah mereka sepakati

Tahap 4 Organizing: siswa menyiapkan hasil kerja dalam bentuk laporan Siswa juga menetukan petugas presentasi

\begin{tabular}{ll}
\hline Tahap 5 & $\begin{array}{l}\text { Presenting: siswa melakukan } \\
\text { presentasi laporan akhir }\end{array}$ \\
\hline Tahap 6 & $\begin{array}{l}\text { Evaluating: siswa melakukan } \\
\text { evaluasi dengan memberi tanggapan } \\
\text { terhadap hasil presentasi dari }\end{array}$
\end{tabular}

kelompok lain

Guru bersama siswa membuat kesimpulan

Keberhasilan tahapan pelaksanaan pembelajaran investigasi kelompok dalam pembelajaran matematika, maka menurut Asma (2006) sangat tergantung dengan latihanlatihan berkomunikasi dan berbagai keterampilan sosial lain yang dilakukan sebelumnya.

Tujuan penelitian ini adalah untuk mengetahui peningkatan kemampuan komunikasi matematis siswa kelas X SMA melalui penerapan model pembelajaran invstigasi kelompok. Adapun manfaat penelitian bagi guru dapat menambah informasi, masukan dan referensi dalam melaksankan proses pembelajaran terutama untuk meningkatkan keaktifan siswa dalam meningkatkan kemampuan komunikasi matematis siswa. Manfaat bagi siswa untuk meningkatkan keaktivan siswa dalam proses pembelajaran matematika. Manfaat bagi sekolah untuk memberikan sumbangan yang baik pada sekolah dalam rangka perbaikan dan peningkatan mutu pendidikan.

\section{METODOLOGI PENELITIAN}

Penelitian ini dilaksanakan di SMA Negeri 1 Selesai. Populasi dalam penelitian ini adalah seluruh siswa kelas X SMA Negeri 1 Selesai semester ganjil Tahun Pelajaran 2019/2020 dengan jumlah seluruh populasi adalah 354 siswa.

Pengambilan sampel dengan cara random. Berdasarkan jumlah populasi kelas $\mathrm{X}$ SMA Negeri 1 Selesai yang banyak serta homogen dan tidak memperhatikan strata yang ada dalam populasi maka sempel yang digunakan dalam penelitian ini yaitu kelas XMIA1 berjumlah 36 siswa sebagai kelas kontrol yang menerapkan pembelajaran matematika secara konvensional dan kelas X- 
MIA2 berjumlah 36 siswa sebagai kelas eksperimen dengan menerapkan pembelajaran investigasi kelompok.

Jenis penelitian ini adalah quasi eksperiment (eksperimen semu) dengan posttest only control group design.

Tabel 2. Desain Penelitian

\begin{tabular}{|llll|}
\hline $\mathrm{E}$ & $\mathrm{O}_{1}$ & $\mathrm{X}$ & $\mathrm{O}_{2}$ \\
& & & \\
\hline $\mathrm{K}$ & $\mathrm{O}_{1}$ & & $\mathrm{O}_{2}$ \\
\hline
\end{tabular}

\section{HASIL PENELITIAN}

Hasil rata-rata pretes kemampuan komunikasi matematis siswa di kelas eksperimen adalah 59,37 dan nilai rata-rata pretest kelas konvensional adalah 52,11. Data pretes kemampuan komunikasi matematis siswa berdistribusi normal dengan nilai varians sama (homogen). Hasilnya adalah tidak ada perbedaan kemampuan komunikasi antara kelas kontrol dan kelas eksperimen. Ini berarti penelitian untuk sampel ini dapat dilanjutkan.

Setelah diberikan pretes untuk kedua kelas selanjutnya untuk kelas eksperimen diberi perlakuan dengan menerapkan metode pembelajaran kooperatif tipe investigasi kelompok dan kelas kontrol tidak diberi perlakuan. Setelah perlakuan pada kelas eksperimen selesai dilaksanakan, untuk kedua kelas diberi postes kemampuan komunikasi matematis pada materi SPLTV dan diperoleh hasilnya pada Tabel 3 .

Tabel 3. Data Postest Kemampuan Komunikasi Matematis Siswa Kelas Eksperimen dan Kelas Kontrol

No Statistik $\begin{gathered}\text { Kelas } \\ \text { Eksperimen }\end{gathered}$

\begin{tabular}{cccc} 
& & \multicolumn{2}{c}{$\boldsymbol{p}$-ISSN $\mathbf{2 5 2 8} \mathbf{- 0 7 7 5}$} \\
& Skor tertinggi & 100 & 80 \\
\hline 3 & Skor terendah & 66 & 52 \\
\hline 4 & Rata-rata & 78,11 & 69,23 \\
\hline 5 & Simpangan & 10,12 & 10,22 \\
\hline 6 & baku & & 73,22
\end{tabular}

Dari hasil pemberian postest diperoleh nilai rata-rata kemampuan komunikasi matematis siswa kelas eksperimen adalah 78,11 dan nilai rata-rata kemampuan komunikasi matematis siswa kelas kontrol adalah 69,23. Sedangkan nilai simpangan baku kemampuan komunikas matematis siswa kelas eksperimen adalah 10,12 dan nilai simpangan baku kemampuan komunikasi matematis siswa kelas kontrol adalah 10,22. Untuk melihat keragaman nilai rata-rata kemampuan komunikasi matematis siswa di kelas eksperimen dan kelas kontrol maka dicarilah nilai variansnya dengan menghitung jumlah kuadrat dari selisih nilai data observasi dari nilai rata-rata, kemudian dibagi dengan jumlah observasi. Nilai varians data postes kemampuan komunikasi matematis siswa dikelas eksperimen dan kelas kontrol adalah 78,11 dan 73,22. Hal ini menunjukkan bahwa kemampuan komunikasi matematis dikelas eksperimen lebih beragam dibandingkan dengan kemampuan komunikasi matematis di kelas kontrol. Uji normalitas dan homogenitas untuk data postes diperoleh bahwa data berasal dari populasi homogen dan berdistribusi normal.

Berdasarkan hasil uji normalitas dan homogenitas kelas eksperimen dan kelas kontrol diatas, diperoleh bahwa kedua sampel berasal dari populasi yang homogen dan berdistribusi normal. Selanjutnya data dianalisis dengan melakukan pengujian hipotesis. Pengujian hipotesis dilakukan untuk mengetahui ada pengaruh signifikan metode 


\section{Jurnal Serunai Ilmu Pendidikan \\ Vol.6, No.1, Juni 2020 \\ e-ISSN $2621-2676$ \\ p-ISSN 2528 - 0775}

pembelajaran kooperatif tipe investigasi kelompok terhadap kemampuan komunikasi matematis siswa SMA. Dengan menggunakan uji-t untuk melihat apakah ada perbedaan nilai postes kemampuan komunikasi matematis siswa SMA yang diajar menggunakan metode pembelajaran kooperatif tipe investigasi kelompok dengan konvensional, dengan hipotesis penelitiannya adalah:

H0: postes kemampuan komunikasi matematis siswa SMA yang diajar menggunakan metode pembelajaran kooperatif tipe investigasi kelompok sama dengan konvensional.

$\mathrm{H1}$ : postes kemampuan komunikasi matematis siswa SMA yang diajar menggunakan metode pembelajaran kooperatif tipe investigasi kelompok tidak sama dengan konvensional.

Kriteria pengujian adalah tolak $\mathrm{H} 0$ jika $t_{\text {hitung }}>t_{\text {tabel }}$.

Dari hasil perhitungan data postes kemampuan komunikasi matematis siswa diproleh $t_{\text {hitung }}=13,52$ dan $t_{\text {tabel }}=1,667$. Kesimpulan pengujian hipotesisnya adalah $t_{\text {hitung }}>t_{\text {tabel }}$ maka $\mathrm{H}_{0}$ ditolak dan $\mathrm{H} 1$ tidak ditolak, jadi pernyataan postes kemampuan komunikasi matematis siswa SMA yang diajar menggunakan metode pembelajaran kooperatif tipe investigasi kelompok tidak sama dengan konvensional tidak ditolak.

\section{PEMBAHASAN}

Berdasarkan uraian diatas bahwa ada pengaruh metode pembelajaran kooperatif tipe investigasi kelompok terhadap kemampuan komunikasi matematis siswa kelas X SMA. Hasil penelitian yang didapatkan ini sesuai dengan hasil penelitian dari beberapa peneliti terdahulu.

Hasil penelitian Sufena, E., Suyono, S., \& Hakim, L. (2018) menyatakan bahwa terdapat perbedaan kemampuan komunikasi matematis siswa yang belajar melalui Metode Kooperatif Tipe Investigasi Kelompok dibandingkan dengan siswa yang mendapat pembelajaran konvensional. Nurhasanah, (2011) menghasilkan penelitian bahwa model pembelajaran investigasi kelompok berpengaaruh lebih baik terhadap kemampuan komunikasi matematik siswa dari pada model pembelajaran konvensional.

Hal ini memungkinkan terjadi karena pada metode pembelajaran investigasi kelompok, guru hanya sebagai fasilitator sehingga siswa dituntut untuk lebih berperan serta dan terlibat aktif secara maksimal. Sejak tahap pertama dalam menentukan topik dan permasalahan apa yang akan dipilih oleh siswa, siswa memilih dan memahami permasalahan dan bagaimana melaksanakan investigasi (penyelidikan) untuk menyelesaikan masalah. Pada tahap penyelidikan siswa berdiskusi dengan temannya dibantu oleh guru untuk menyelesaikan tugasnya sampai pada penyusunan laporan kerja kelompok. Kemampuan komunikasi akan terbentuk ketika tahap presentasi kelompok. Kelompok yang lain akan saling mengevaluasi. Suasana belajar yang melibatkan aktif siswa seperti ini menekankan pada partisipasi dan aktivitas siswa untuk mencari sendiri materi (informasi) pelajaran yang akan dipelajari.

\section{KESIMPULAN}

Berdasarkan hasil penelitian dan pengolahan data maka dapat ditarik kesimpulan yaitu ada pengaruh signifikan pembelajaran matematika dengan menggunakan model investigasi kelompok terhadap kemampuan komunikasi matematis siswa kelas X SMA. 


\section{DAFTAR PUSTAKA}

Al. Krismanto, dan Widyaiswara. 2003. Beberapa Teknik, Model, dan Strategi dalam Pembelajaran Matematika. Yogyakarta: Depdiknas PPPG Matematika.

Arends, R.I. 2008. Learning To Teach Belajar Untuk Mengajar Edisi Ketujuh/Buku Dua. Yogyakarta: Pustaka Belajar.

Arikunto, Suharsimi. 2014. Prosedur Penelitian Suatu Pendekatan Praktik. Cet.XV, Jakarta: Rincka Cipta.

Asma, Nur. 2006. Model Pembelajaran Kooperatif. Departemen Pendidikan Nasional Direktorat Jenderal Pendidikan Tinggi. Jakarta.

Dimyati, Mudjiono. 2009. Belajar dan Pembelajaran. Jakarta: Rineka Cipta

Hodiyanto, Kemampuan Komunikasi Matematis Dalam Pembelajaran Matematika. Jurnal Pendidikan Matematika, ISSN : $2088-687 x$

NCTM. (2000). Principles and standards for school mathematics. Reston, Virginia: NCTM

Nurhasanah, Yeni., 2011. Pengaruh Penerapan Model Pembelajaran Investigasi Kelompok Terhadap Kemampuan Komunikasi Matematik Siswa SMA.Skripsi. FPMIPA. UPI

Ramadhani, Evi., Mardiati. (2020) Pengaruh Model Pembelajaran Snowball Throwing terhadap Kemampuan Komunikasi Matematis Siswa pada materi matriks Kelas XI SMK Negeri I Stabat Tahun Pelajaran 2019/2020. Jurnal Serunai Matematika. 12(1), 1925

Slavin. 2009. Cooperative Learning. Bandung: Nusa Media.

Sufena, E., Suyono, S., \& Hakim, L. (2018). Pengaruh Penerapan Metode Kooperatif Tipe Investigasi Kelompok Terhadap Kemampuan Komunikasi Matematis dan Self Confidence Siswa SMP. Journal of Mathematics Learning, 1(1), 27-38. https://doi.org/10.30653/004.201811.3

Sugiyono, 2012. Metode Penelitian Pendidikan, Cet. I, Bandung: Alfabeta.

Utami Citra, dkk, 2015. Pembelajaran Model Generatif Dengan Strategi Group Investigation Untuk Meningkatkan Kemampuan Komunikasi Matematis Siswa, Unnes Jurnal Matematika 